\title{
Major Salivary Gland Cancer pN2b TNM Finding v6 and v7
}

National Cancer Institute

\section{Source}

National Cancer Institute. Major Salivary Gland Cancer pN2b TNM Finding v6 and v7. NCI

Thesaurus. Code C65090.

Major salivary gland cancer with metastasis in multiple ipsilateral lymph nodes, none more than $6 \mathrm{~cm}$ in greatest dimension. (from AJCC 6th and 7th Eds.) 